\title{
Scholars and Literati at the Universitas Lovaniensis (1425-1797)
}

\author{
Guillaume Catoire \\ Julie Duchêne
}

\author{
Valentine Debois \\ Maximilian Ganterer
}

\author{
David de la Croix \\ Mara Vitale
}

\author{
IRES/LIDAM, UCLouvain
}

\begin{abstract}
This note is a summary description of the set of scholars and literati who taught at the Universitas Lovaniensis, commonly referred to as the University of Louvain or University of Leuven, from its inception in the 15th century to its abolishment in 1797 following the cession to the French Republic of the Austrian Low Countries.
\end{abstract}

\section{The University}

WE looking favourably upon these supplications, in virtue of the present [bull], that as from now there be in the aforementioned town a University comprising all the faculties, with the exception of theology, and that in the years to come this university be established and maintained forever in this place[...] (Cavalieri 2019).

With these words in the papal bull Sapientiae Immarcessibilis, Pope Martin V declared the creation of the Universitas Lovaniensis. It was December 9, 1425, and the old University of Louvain was created in the Flemish city of Leuven. Pope Martin V endorsed the requests of the clergy and town council who had long demanded that a university be established. He entrusted John IV, Duke of Brabant, with the task of founding the university, which included the faculties of arts, law, and medicine. A few years later, in 1432, the faculty of theology was added. It soon became one of the most prestigious universities in Northern Europe, attracting distinguished scholars. In the 16th century, Louvain was the seat of Jansenism and would remain a bastion of Augustinian theological thought until the end. The Faculty of Theology was the first to condemn the Protestant doctrine, and the proposed text allowed the elaboration of the Roman censorship of 1520 in the Catholic Netherlands (Hiraux 2003). In 1517, inspired by Erasmus, a trilingual college (Latin, Greek, and Hebrew) was created, a unique model in Europe, which inspired the Collège de France (De la Croix 2021). In 1797, sovereignty over the Southern Netherlands was officially transferred to France by the Treaty of Campo Formio. The Abolition Law abolishing all colleges and universities in the Republic of 1793 became applicable to the University of Louvain, which closed on November 9, 1797. The major, rich library of 80,000 books was transferred to the École Centrale in Brussels, designated by law as the official continuation and replacement of the old University of Louvain. About 5,000 of the most valuable volumes were taken to the National Library in Paris $(\mathrm{BnF})$.

\section{SOURCES}

To have a comprehensive list of the scholars who taught at the University of Louvain, we used several sources. First, we used the history of the city of Leuven (De Ram 1861) which provides a list of rectors of the University. As rectors were elected for six months, this list contains many names. We completed the sample with information from the articles by Brants (1906) for the Faculty of Law, and Tricot-Royer (1927) for the Faculty of Medicine. In a second step, we browsed the electronic 
versions of the biographical dictionaries of Eloy (1755) (medicine) and De Feller (1849). The coverage of the trilingual college was improved thanks to the book by Nève (1856). In a third step, we read Lamberts and Roegiers (1990), which allowed to add many names. Next, we browsed the Repertorium Academicum Germanicum (Schwinges and Hesse 2019), which enabled us to obtain almost perfect coverage of the period 1425-1550. Finally, we compared our sample with the one used in the Lovaniensia project ((http://www.lovaniensia.be/lovaniensia/)), which is itself based on additional sources. This project aims at publishing digitized versions of all printed books by members of the University of Louvain. We additionally consulted the online databases of the Royal Academy of Belgium and the Biografisch Portaal van Nederland to complete the biographical information. On the whole, we are still probably missing some obscure scholars, but all the important ones should be covered.

\section{SOME STATISTICS}

Table 1 shows some descriptive statistics. There are 1,145 scholars and literati in total, a high number for a university which has no biographical dictionary of alumni or professors and is only covered by a patchwork of sources. The year of birth is known for $35.6 \%$ of them. For these individuals, the mean age at appointment is 31.6 years, which is quite young compared to the other universities, especially at the start of the university. Longevity (mean age at death \& expected age at death when 30) is relatively low, around 64 years for both measures, but improving in the last period, consistently with the literature on the historical life expectancy of elites (Stelter, De la Croix, and Myrskylä 2021). The birth place is known for $61.4 \%$ of the individuals. For them, the median distance between birth and the city of Leuven is $82 \mathrm{~km}$. The median distance consistently drops over time, indicating a less and less pronounced international nature. Finally, $15.5 \%$ of the scholars have a Wikipedia page (in some language), but $35.4 \%$ of them have left a footprint in the catalogues of the libraries of the world, Worldcat. This last number is not so low, and fully justifies the Lovaniensia project, which aims at digitizing the printed oeuvre of a majority of these individuals.

\begin{tabular}{|c|c|c|c|c|c|c|}
\hline \multicolumn{2}{|c|}{ Period } & \multirow{2}{*}{$\begin{array}{l}\text { nb. } \\
\text { obs }\end{array}$} & \multirow{2}{*}{$\begin{array}{l}\text { \% birth year } \\
\text { known }\end{array}$} & \multirow{2}{*}{$\begin{array}{l}\text { mean age } \\
\text { at appoint. }\end{array}$} & \multirow{2}{*}{$\begin{array}{l}\text { mean age } \\
\text { at death }\end{array}$} & \multirow{2}{*}{$\begin{array}{l}\text { exp. age } \\
\text { at death }\end{array}$} \\
\hline Start & End & & & & & \\
\hline 1348 & 1449 & 220 & 11.9 & 27.8 & 64.8 & 66 \\
\hline 1450 & 1526 & 283 & 25.8 & 30.5 & 60.7 & 60.2 \\
\hline 1527 & 1617 & 280 & 48.9 & 31.7 & 63.3 & 63.6 \\
\hline 1618 & 1685 & 149 & 50.3 & 31.6 & 66.7 & 67 \\
\hline 1686 & 1733 & 90 & 43.3 & 34.7 & 64.5 & 64.8 \\
\hline 1734 & 1800 & 123 & 47.2 & 32.7 & 69 & 69 \\
\hline \multirow[t]{2}{*}{1000} & 1800 & 1145 & 35.6 & 31.6 & $-\overline{6} . \overline{5}$ & 64.4 \\
\hline & & & $\begin{array}{c}\% \text { birth place } \\
\text { known }\end{array}$ & $\begin{array}{l}\text { median distance } \\
\text { birth-institution }\end{array}$ & $\begin{array}{c}\% \text { with } \\
\text { Wikipedia }\end{array}$ & $\begin{array}{c}\% \text { with } \\
\text { Worldcat }\end{array}$ \\
\hline 1348 & 1449 & & 64.4 & 101 & 5.5 & 11.9 \\
\hline 1450 & 1526 & & 72.1 & 89 & 13.8 & 26.5 \\
\hline 1527 & 1617 & & 67.9 & 82 & 28.6 & 45.7 \\
\hline 1618 & 1685 & & 51 & 70 & 16.1 & 53 \\
\hline 1686 & 1733 & & 44.4 & 53 & 5.6 & 45.6 \\
\hline 1734 & 1800 & & 42.3 & 51 & 13.8 & 45.5 \\
\hline 1000 & 1800 & & 61.4 & 82 & $1 \overline{5} . \overline{5}$ & 35.4 \\
\hline
\end{tabular}

Table 1: Summary statistics by period 


\section{FIELDS}

Figure 1 shows the relative importance of fields, broadly defined. In this pie chart, we can see that most of the professors who taught at the University of Louvain worked in the humanities, law, or theology. These three sectors account for more than three quarters of the subjects taught. The last two fields (law and theology) together account for about half of the pie chart. Science and medicine were present but with a relatively small weight.

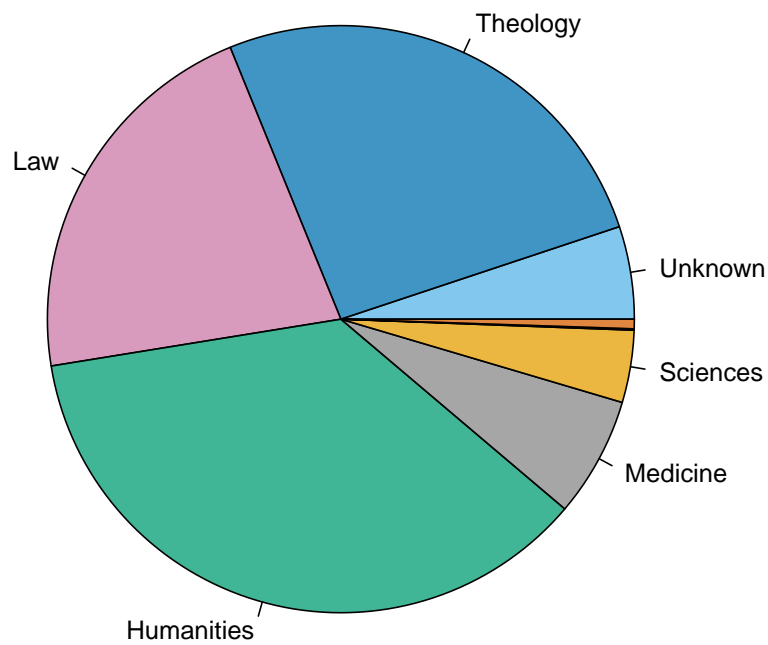

Figure 1: Broad fields at Louvain

\section{Place OF BIRTH}

Figure 2 is a plot of the places of birth of all the scholars of Louvain, with a second graph focusing on the Low Countries. Above all, the recruitment pool of Louvain encompassed the whole of the Low Countries, from the North of the Netherlands to the South of Belgium. Some scholars came from farther away, including the North of Spain, the North of Italy, the Middle East, England, and more importantly, Ireland (concentrated over the period 1618-1685). This can be explained by the attraction of the Irish College founded in 1609.

\section{HUMAN CAPITAL OF SCHOLARS AND LITERATI}

For each person in the database, we compute a heuristic human capital index, identified by combining information from Worldcat and Wikipedia using principal component analysis. We also compute the notability of the university at each date by averaging the human capital of the scholars active at the University of Louvain 25 years before that date. The details are given in the Appendix.

Figure 3 shows the names of all of the scholars with a positive human capital index. The orange line plots the notability of the university. The vertical green lines (rug plot) show the distribution of all scholars, including the obscure ones, over time.

The notability of the University of Louvain follows a very clear pattern: a rise after its inception over 1425-1500, a golden age over 1500-1600, and then a slow decline. During its golden age, several members of the University of Louvain contributed significantly to the beginning of the Scientific Revolution (Applebaum 2003). Afterwards, the university was engulfed in a strong factional fight between Jansenists and mainstream Catholics. In addition, the defensive position of the Church during the Counter-Reformation did not help adjust teaching and research to the new vision of the 

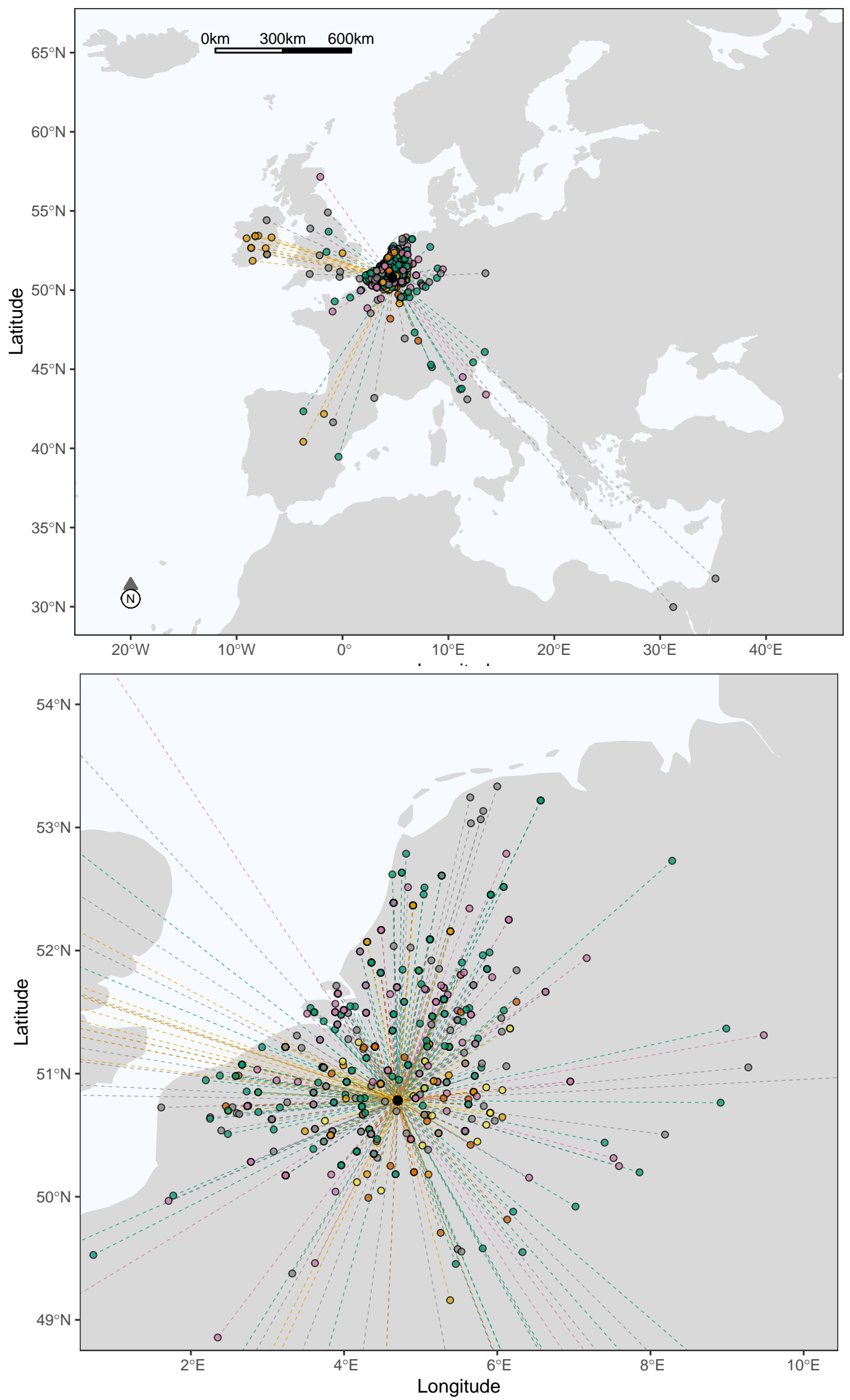

$\begin{array}{lllllll}* & \circ & 1348-1439 & \circ & 1537-1617 & \circ & 1686-1733 \\ & \circ & 1440-1526 & \circ & 1618-1685 & \circ & 1734-1800\end{array}$

Figure 2: Place of birth of the scholars and literati at the University of Louvain 
world promoted by the development of sciences elsewhere in Europe. However, this view should be qualified by the fact that Cartesianism rapidly entered Louvain, precisely because of Jansenism (Coesemans 2019).

\section{TOP 8 PROFESSORS}

We now provide a brief overview of the eight professors with the highest human capital index.

Justus Lipsius (Overijse 1547 - Leuven 1606) A philosopher and humanist. He taught at the universities of Jena, Leiden, and Louvain. His recruitment in Louvain in 1592 was strongly pushed for by Laevinus Torrentius, the Bishop of Antwerp. He was given the chairs of ancient history and Latin at the Collegium Trilingue. Lipsius was happy to play a role in the restoration of the Alma Mater of Louvain, which had been gravely damaged by the consequences of the plague and the great political instability of this period. His method of teaching was greatly popular among the students. His fame was so great that Archdukes Albert and Isabella, the day after their Joyous Entry in Louvain in November 1599, attended one of his lectures. In Jena, he converted to Lutheranism, which he abandoned when he arrived in Louvain, where he reconciled with the Roman Catholic Church in 1591. He died in Leuven in 1606.

Joannes Lodovicus Vives (Valencia 1493 - Brugge 1540) was a Spanish scholar and humanist of the Renaissance. He was a theologian, philosopher, and pedagogue. However, he is best known as one of the fathers of psychology. He was the first to develop certain key ideas, notably around emotions, memory, and learning, which today form the basis of modern psychological perception. In 1509, he left Spain both to escape the persecution of the Spanish Inquisition threatening his Jewish family and to enrol at the Sorbonne in Paris. Yet his Parisian experience was short-lived. He was disappointed by the level of the courses, found himself to be the target of hazing, and disliked the Parisian atmosphere, so that he left the French capital for Bruges in 1512. In 1519, he obtained a full professorship at the University of Louvain. There, he also met Erasmus, a decisive encounter for Juan Luis Vives. Vives's erudition appealed to Erasmus, who became his mentor. Throughout his life, Vives would try to imitate him in everything. Vives also stayed several times in England where he was appointed professor at Oxford University in 1523. However, his opposition to the remarriage of King Henry VIII to Ann Boleyn in 1533 led to the loss of his professorship, imprisonment, and then banishment for life. He spent the last years of his life in Bruges, where he died in 1539.

Adrianus Florentii (Utrecht 1459 - Rome 1523) was pope from 1522 until 1523 under the name Adrian VI. Florentii started his academic career as a professor mainly teaching philosophy and theology at the Paedagogium Porci of the University of Louvain. His strong ecclesiastical interest led him to reach a doctoral degree in theology, and hold a chair in it from 1490 onwards at the University of Louvain. Florentii had an excellent scholastic reputation and his work even received attention from Desiderius Erasmus. After having been appointed Bishop of Tortosa, he took part in the Spanish Inquisition as Grand Inquisitor Florentii and was elected as Pope in 1522.

Johannes Baptista Van Helmont (Brussels 1577 - Vilvoorde 1644) became famous for his advances in the field of chemistry. Born in a good family, he enrolled at the University of Louvain. Van Helmont first studied philosophy, but afterwards he was seized by a vision illustrating his mysticism and turned to medicine. He taught surgery for a short time at the College of Medicine (Hiraux 2003, de Belgique 1883). His interest in concrete things and natural phenomena made him a rigorous observer and experimenter. His belief in the philosopher's stone on the one hand, and his discoveries, notably concerning gases or gastric juice on the other hand attest to the connection he made between chemistry and alchemy. Today, buildings of UCLouvain, both in Louvain-la-Neuve and in Brussels, bear his name. 


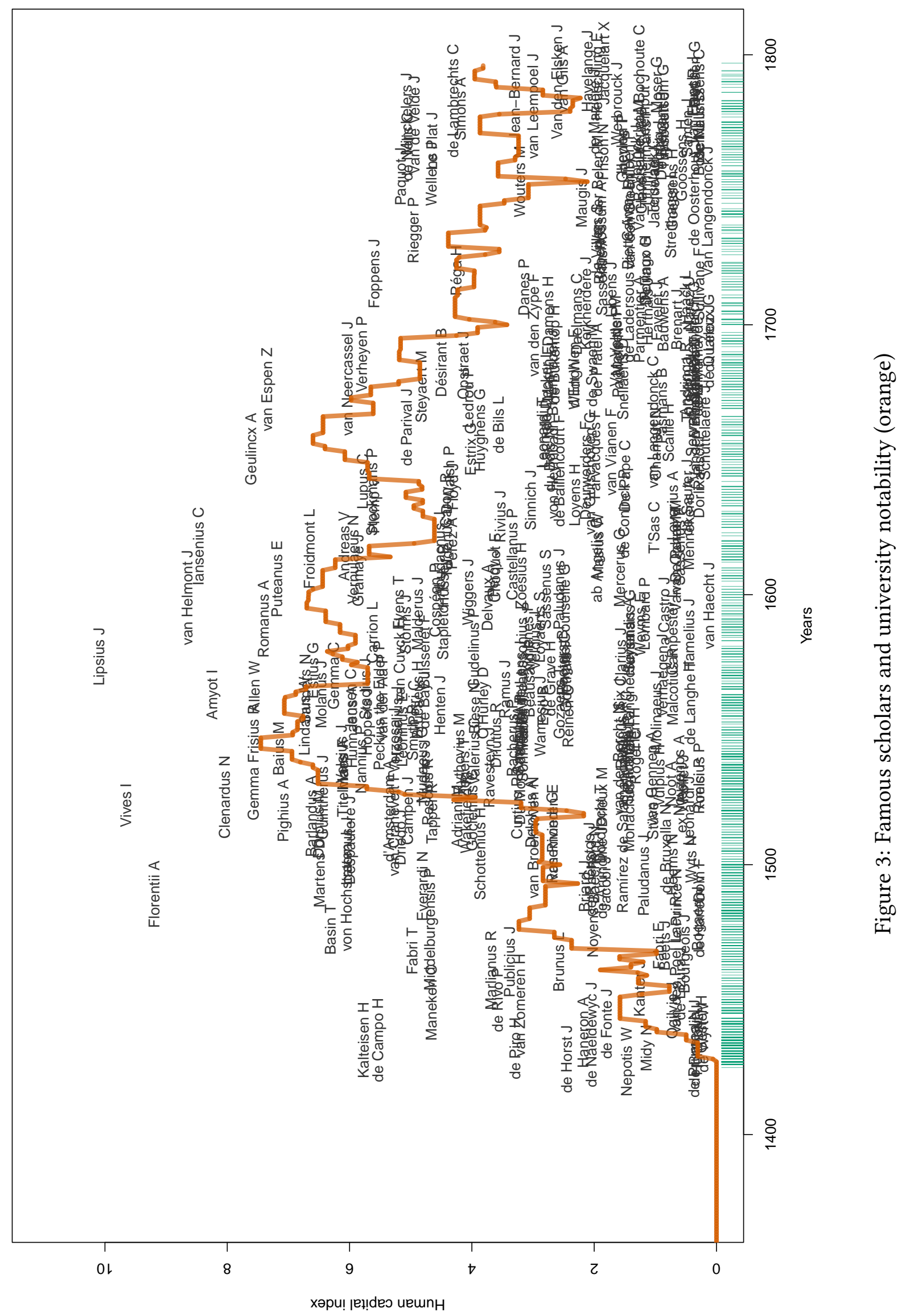


Cornelius Jansen (Acquoy 1585 - Ypres 1638) Cornelius Jansen, also known by his Latin name Jansenius, was the originator of Jansenism, a Catholic religious movement that developed in the 17th century. This movement proposed a return to the ideas of Saint Augustine on divine grace. This grace alone allowed the souls of sinners to be saved. The Jansenists, the practitioners of this movement, opposed the Jesuits, whom they accused of being too lenient with sinners. In 1602, he entered the Paedagogium Falconis of the University of Louvain. When he graduated, he went to Paris and Bayonne and returned to Louvain in 1617, where he became involved in the University's resistance against the Jesuits. He spent the rest of his life in Leuven writing his "Augustinus," the founding text of Jansenism. He was condemned by the Roman Catholic Church in 1653 and his followers were persecuted by Louis XIV. He was the Bishop of Ypres.

Iacobus Amyot (Melun 1513 - Auxerre 1593) A humanist and churchman, he distinguished himself by his skills as a translator. His academic career began in France, in Paris first and then in Bourges, where he developed his mastery of Greek and Latin letters, but he also became a man of the world, soon solicited by the powerful, such as François I, who asked him in 1542 to translate Plutarch's Parallel Lives. In 1563, Aymot was authorized to teach the Greek grammar of the humanist Clenardus in an auditorium of the Faculty of Medicine (UCLouvain 1874). This success in the field of letters went hand in hand with his accession to ecclesiastical functions, including that of Bishop of Auxerre in 1570.

Nicolas Cleynaerts (Diest 1495 - Granada 1541) known in the Republic of Letters as Nicolaus Clenardus, and in French letters as Nicolas Clénard, was enrolled at the University of Louvain in 1512 as a student in the Paedagogium Porci. These studies enabled him to study ancient languages. After a short time, he discovered a passion for Arabic. At the end of his studies, he was appointed president of the Houterlé College at Louvain for ten years. He taught Hebrew and Greek at the Collegium Trilingue. During these 10 years, he taught himself Arabic. After that, he traveled to Spain (via France) at the request of Christopher Columbus's son, Fernand, in order to organize his library (the Biblioteca Colombina). He practised his Arabic in Spain and perfected it in Africa, more specifically in Fez.

Arnold Geulincx (Antwerp 1624 - Leiden 1669), also known by the pseudonym Philaretus, was a philosopher. Geulincx studied philosophy and theology at the University of Louvain, where he became a professor in 1646 . He was dismissed in 1658, probably because of his sympathies for Jansenism and Protestantism (Vander Haeghen 1886). He moved to Leiden, where he converted to Calvinism. After a period of economic difficulties, he obtained a lectureship in logic in1662 and became a professor extraordinary of philosophy and ethics in 1665 . He was a follower of the thought of René Descartes, and is considered one of the founders of occasionalism, according to which the Cartesian correspondence between psychic activity (res cogitans) and bodily activity (res extensa) is derived from an agreement established between them by God. Geulincx died of the plague in 1669 in Leiden.

\section{The Jesuits at Louvain}

Whereas Jesuits were put in charge of university teaching at some universities, they did not have this opportunity at Louvain. However, although they were not formally professors at the university, their presence since 1566 in the Flemish city influenced the thinking of the time, contributing to the human capital of the place. The most famous are listed here.

Robertus Bellarminus (1542 Montepulciano - 1621 Rome) A Jesuit theologian, he was proclaimed Doctor of the Church in 1931. He began his theological studies in Padua and completed them in Leuven in 1570, the year when he received priestly ordination in Ghent. As a preacher, he distinguished himself for his eloquence and ability to counter Calvinist theses, which were 
spreading in Flanders. He was entrusted with the teaching of theology at the Jesuit College, a position which he held for 6 years. The subject of his course was the Summa Theologica of Thomas Aquinas. In the Lectiones Lovaniensis, we find the first theological reflections that later led to his main work, the Disputationes de controversiis (1581). This work, which had great resonance throughout Europe, is considered as the first attempt to systematize the various theological controversies of the time. After this period in Leuven, he was called back to Rome by Pope Gregory XIII, who entrusted him with the chair of "controversies" (apologetics), which had recently been established at the Gregoriana University (see De la Croix and Karioun (2021)).

Andreas Tacquet (Antwerp 1612 - Antwerp 1660) was a professor of mathematics at the Jesuit College from 1646 to 1655 . He engaged primarily with geometry, and in his most influential contribution, Cylindricorum et annularium (1659), he studied the forms of solids. Tacquet was a significant member of his Jesuit Order. There is a controversy about whether he was a pioneer in infinitesimal calculus, as is argued for example on his Wikipedia page in French, or if instead, he led the fight against infinitesimal calculus, as Alexander (2014) argues in his recent book.

\section{RELATED SCHOLARS}

Beyond those who taught at the University of Louvain, at least three important individuals are related to the university. They are counted in the data for all figures but Figure 3.

Desiderius Erasmus (Rotterdam 1466 (?) - Basel 1536), also known as Erasmus of Rotterdam, is one of the greatest humanist figures of the 16th century. The exact year of his birth is not known. A regular canon of St Augustine, he was a philosopher and theologian. Today, he is best known for four of his works: In Praise of Folly (1511); his anthology of several thousands of Greek and Latin quotations, Adagia (1500); his collection of didactic essays, Colloquies (1522); and his Greek-to-Latin translation of the New Testament (1516). In his writings, he was interested in many subjects related to the problems of his time: art, education, religion, war, philosophy, etc. Nicknamed the "Prince of the Humanists," he played a central part in the establishment of the "Republic of Letters" in Europe. Erasmus is also known for his numerous trips across Europe between 1499 and 1514 to meet thinkers, humanists, and scientists such as Thomas More. Among his destinations was Anderlecht, where he stayed between May and October 1521. A member of the University of Louvain where he was matriculated and stayed from 1517 to 1521, he always refused a formal position as professor. He published several works with the Leuven printer Dirk Martens. He is also seen as the founding father of the Collegium Trilingue (Vocht 1951), and although he never held a teaching position there, he served on the College council. Founded in 1517 thanks to the patronage of the humanist Hieronymus de Busleyden, the Collegium Trilingue was based on the model of the Colegio Trilingüe of the University of Salamanca and prefigured the Collège de France. The aim of the founders was to promote the teaching of the three ancient languages: Latin, Greek, and Hebrew. Once the College was inaugurated, Erasmus continued to be active in ensuring its success. In particular, he helped to recruit the best teachers.

Andreas Vesalius (Brussels 1514 - Zakynthos 1564) was a Belgian anatomist. Born to a family of physicians, Vesalius became himself a doctor of medicine. He studied medicine inter alia at the University of Louvain. In the course of his medical studies, he dissected dead human bodies at Louvain. He was never offered to teach at this university. Thanks to his exceptional anatomical abilities, especially with a surgical knife, Vesalius was offered a chair in medicine at the University of Padua shortly after receiving his doctoral degree. There, he was granted freedom of research, and performed a large number of dissections. His treatise on the structure 
of the human body De humani corporis fabrica libri septem (1543) is regarded as a foundational work of present-day anatomy. The University of Louvain has named a lecture hall after him.

Gerardus Mercator (Rupelmonde 1512 - Duisburg 1594) With Vesalius (above), Mercator is probably the best known student of the University of Louvain. He became famous for his world map based on a new projection whose unique properties were particularly suited to marine navigation. Mercator was a student of Gemma Frisius (see the Mathematics Genealogy Project https://www.genealogy.math.ndsu.nodak.edu). Mercator never taught publicly at Louvain, but biographers mention he gave private lessons. In 1552, Mercator moved from Leuven to Duisburg, where he taught mathematics at the Academic Gymnasium.

\section{WHO'S WHO ON THE MOON}

Another way to measure the notability of individuals is to look for signs of recognition such as street names... and lunar crater names. The following three professors received this honor, in recognition of their contribution to the advancement of mathematics.

Gemma Frisius (Leuven 1535 - Leuven 1578) was a 16th century cartographer and mathematician. In 1569, he taught medicine at Louvain succeeding to the chair of Professor Nicolas Biesius. His studies of cosmology are also significant. His De Locorum describendorum ratione(1553) is the oldest work describing triangulation and the method to determine longitudes. It is therefore of great importance in the history of geodesy. Some of his pupils, like Mercator and Vesalius, became famous in their respective fields of research.

Andreas Tacquet (Antwerp 1612 - Antwerp 1660), see above.

Joannes Stadius (Antwerp 1527 - Paris 1579) was an astronomer, astrologer, and mathematician. A disciple of Frisius, he obtained the chair of mathematics at the University of Louvain in 1565. In Ephemerides novae et auctae (1556), his major work, Stadius proposes tables that were used to inform scientists about the movement of the stars, to predict the periods of fertility and sterility of the soil, and to defend against diseases or storms that could occur at any time of the year. In 1935, the International Astronomic Union gave his name to a lunar crater located on the near side of the Moon.

\section{WAGES}

The human capital index we have built represents the quality of each scholar as seen from a current perspective, as it uses publications and library holdings as they are now. We now wonder whether our measure is related somehow to the wages the professors obtained during their working life. Wages are not necessarily a good measure of their total income (or their private return on their human capital), because these wages were often completed by income from other sources (such as from positions in the Church), or by income paid in kind (housing, etc). However, at the beginning of the University of Louvain, the wages were paid by the municipality, and other sources of income were limited. It is only after some years that theologians were encouraged to obtain other positions in order to alleviate the budget of the municipality (Paquet 1958).

Figure 4 compares the wages with the human capital index for the initial period of 1425-1450. One fourth (25\%) of the variation across individuals of our measure of human capital is explained by variations in wages. This relies on a few points, of course, but it is nice to find a positive correlation between the two measures of human capital, now and then.

\section{FAMILIES OF SCHOLARS}

We counted 12 father-son pairs among the members of the University of Louvain. Two members of the Jacquelart family taught at Louvain. Joannes-Remigis taught medicine, while his son Xavier, the last professor at the old university and still alive in 1856, was a professor of law. 


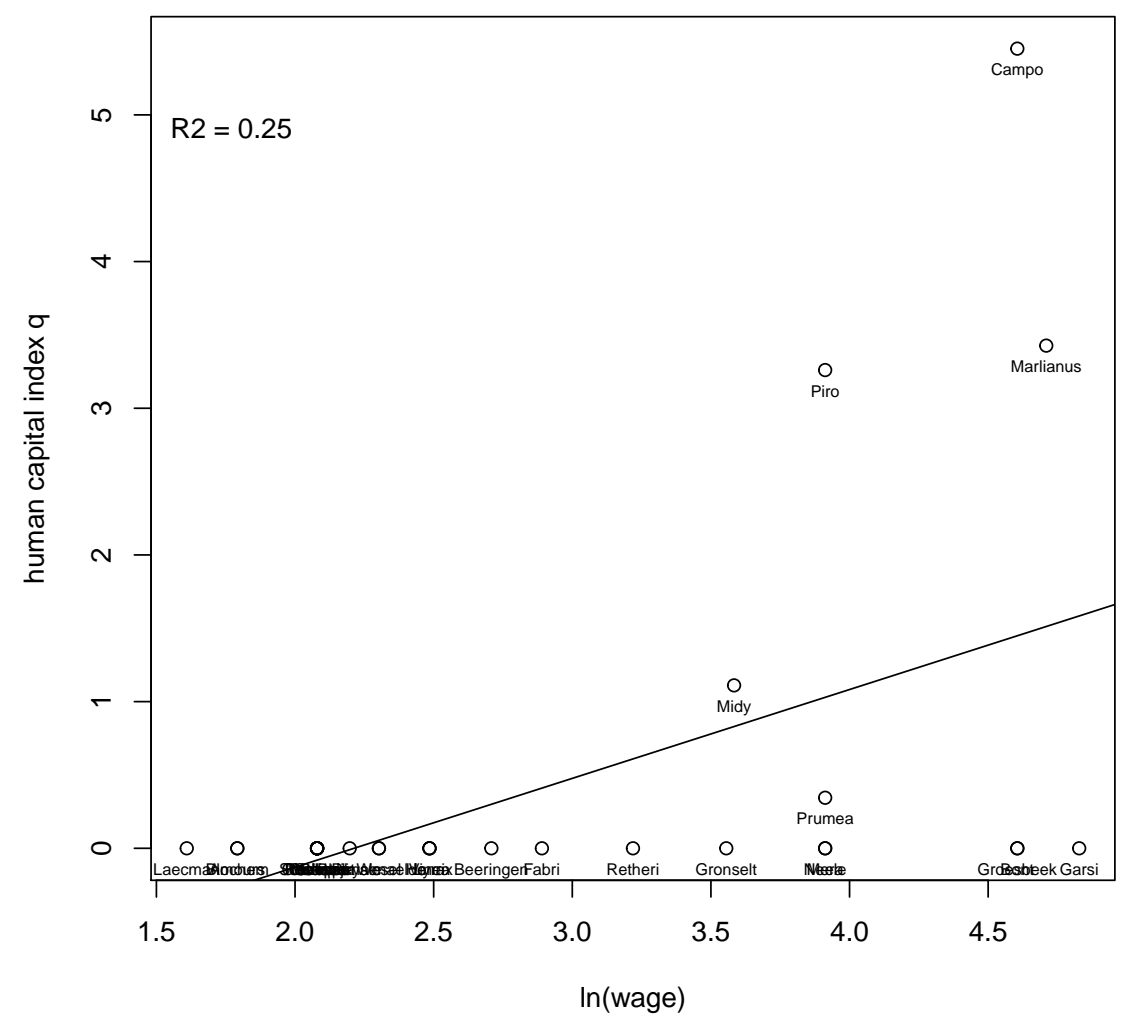

Figure 4: Wages vs Human Capital Index over the period 1425-1450

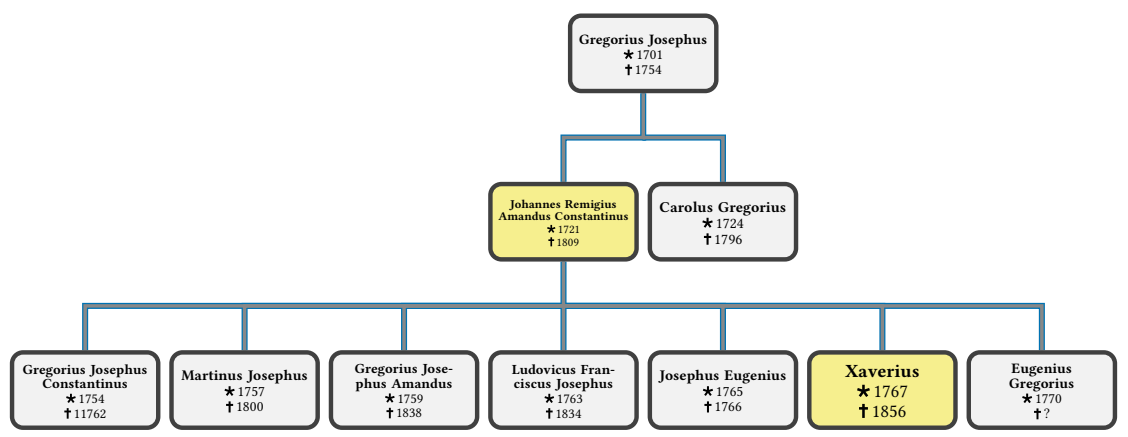

Figure 5: The Jacquelart family. Professors at Louvain in yellow squares

\section{UNIVERSITY NETWORK}

Here, we assume that when a professor occupied a position at more than one university over his/her life, this established a link between those universities. The universities with which the University of Louvain is linked are displayed in Figure 6 During the golden age, 1537-1617, we observe links with several universities in France, the Low Countries, and the Holy Roman Empire. In the last period, 1734-1800, links are restricted to the Italian peninsula (with one exception).

\section{A NETWORK OF INDIVIDUALS}

Another way to look at the intersection between two institutions is to consider the network of scholars. The network of scholars will represent individuals as nodes. Edges (links between individuals) will be assumed when two scholars share the same institution during the same period. Once such a network is built, it can be represented, for example, by the standard Fruchterman-Reingold forcedirected algorithm that groups persons more closely together when they are linked to each other. 


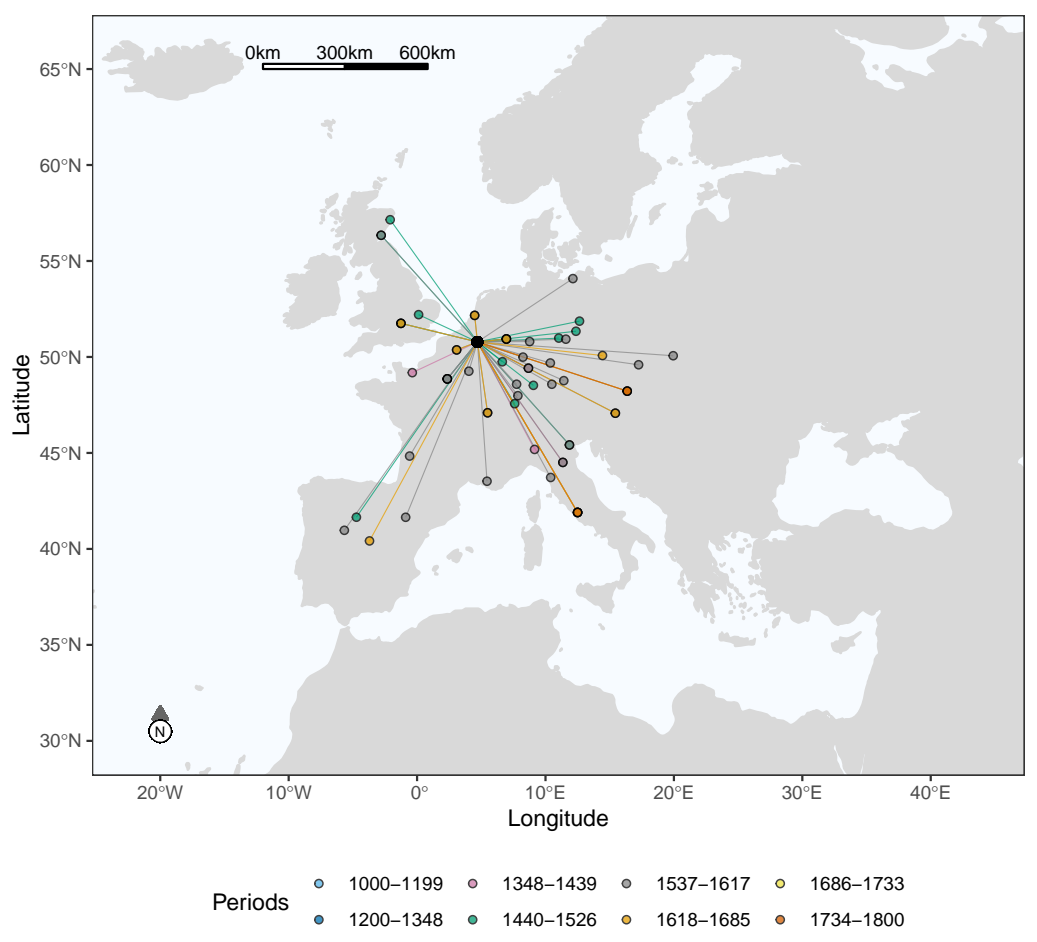

Figure 6: Links between the University of Louvain and other universities through scholars' mobility, by period

Figure 7 shows the network of scholars of the University of Louvain together with those from the nearby university of Leiden, in the Protestant Netherlands. Time flows from right to left. Three professors make bridges between the two universities, with Lipsius being the most known one. After the mid seventeenth century, the two universities follow their own path.

\section{ANECDOTES}

Gemma Frisius's work contributed to the development of the Global Positioning System (GPS) for geolocation. Gemma Frisius worked on triangulation. This is a mathematical technique based on trigonometry that allows distances to be calculated. Although today many techniques have replaced these mathematical calculations, triangulation is still used in the army, when the military does not have radar. Triangulation uses the law of sines, the fact that the sum of the angles of a triangle is 180 degrees and the theorems of Al-Kashi and Pythagoras. Gemma Frisius also proposed a method for determining longitude thanks to precise clocks. In 1533, he wrote a treatise in Antwerp entitled "Libellus De Locorum Describendorum Ratione," which in 16 pages lays the foundations of modern geodesy (the earliest exposition of the principles of geodetic triangulation). In it, he explains how networks of triangles can be used to survey spaces no matter how large.

The annexation of the Netherlands in 1794 by the young French Republic sealed the fate of the University of Louvain, at least temporarily. In 1797, a few months after the election of its last rector, Jean-Joseph Havelange, the suppression of the historical university was decreed by the French administration. This decision was in addition to one taken shortly before, which had already sentenced Havelange to deportation to Cayenne (French Guiana). He was accused of having tried to exorcise a young girl with two priests and, moreover, had refused to take the oath of fidelity to the Republic. These were so many ways to weaken the university even before its official suppression. The rector was arrested on October 27, 1797, and he disembarked at Cayenne on June 6, 1798. His imprisonment was short-lived since, as he was already weakened, he lost his life on September 6 of the same year. 


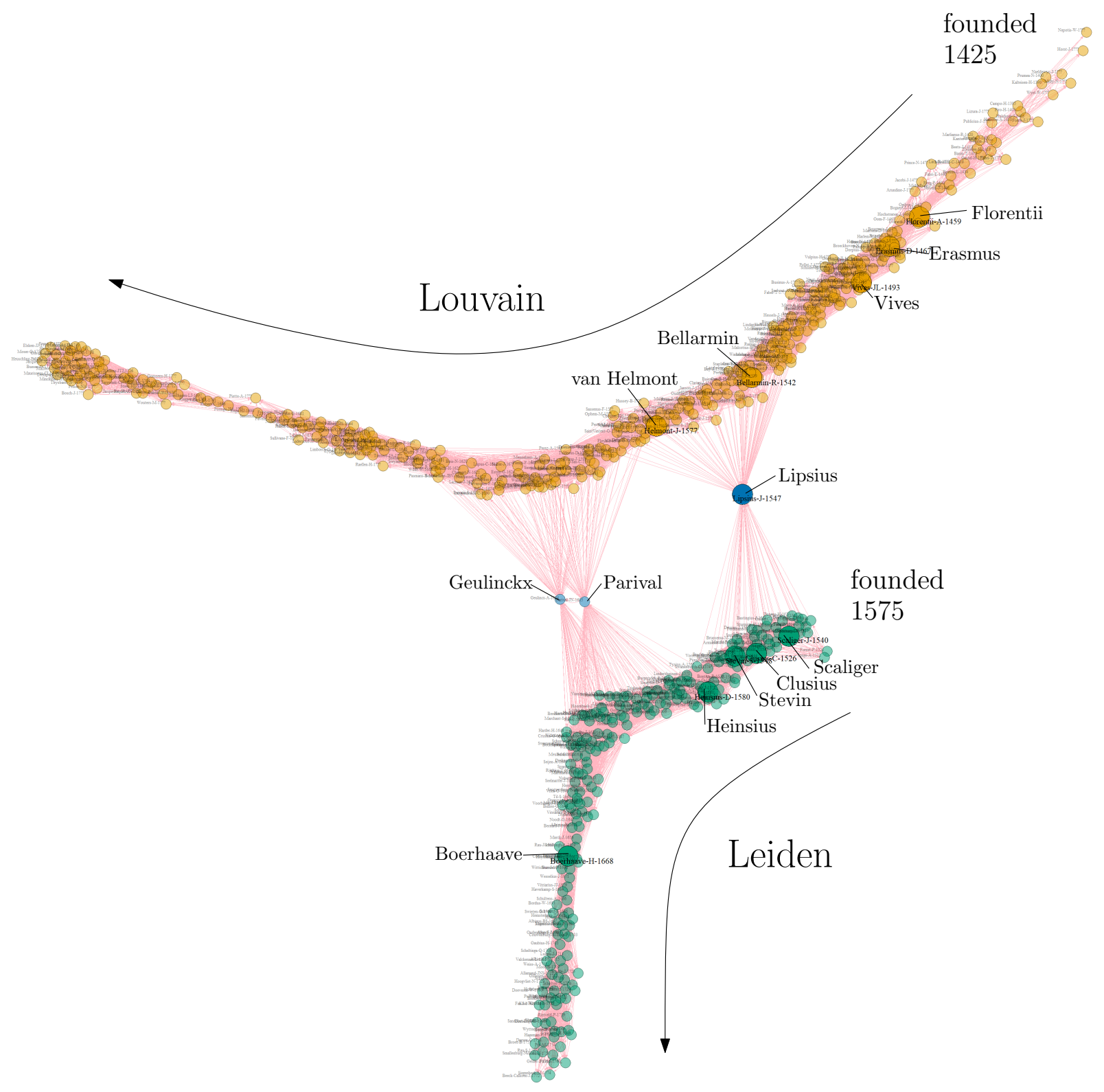

Figure 7: Network of scholars: University of Louvain (orange) and of Leiden (green) 


\section{Final Thoughts}

During the span of its existence, the University of Louvain was the most important centre of higher education within the borders of Belgium. Like a living organism, the University of Louvain was born, grew, and declined. It attained an apogee in the sixteenth century. This apogee was extraordinary, with first-class members who contributed significantly to the humanistic and scientific revolutions in Europe. From then on, the university progressively lost its international nature and ceased to contribute to the advancement of the sciences.

\section{APPENDIX}

The individual human capital index $q_{i}$ of an individual $i$ is given by:

$$
\begin{aligned}
q_{i}= & -1.76+0.43 \ln (\mathrm{nb} . \text { of characters of the longest Wikipedia page }) \\
& +0.40 \ln (\mathrm{nb} . \text { of Wikipedia pages in different languages })+0.47 \ln (\mathrm{nb} . \text { of works in Worldcat }) \\
& +0.46 \ln (\mathrm{nb} . \text { of publication languages in Worldcat }) \\
& +0.47 \ln (\mathrm{nb} . \text { of library holdings in Worldcat })
\end{aligned}
$$

We assume that having no Wikipedia page is similar to having one page with a length of 60 characters and that having no Worldcat page is similar to having a page with one work in one language held by one library. The constant -1.76 normalizes $q_{i}$ at 0 when there is neither a Wikipedia page, nor a Worldcat page. The weights $(0.43,0.40$, etc $)$ are obtained from the first principal component of the five indicators (De la Croix et al. 2020).

The notability $Q$ of a university aggregates the $q$ of the top 5 individuals who were active in the preceding 25 years using the following formula:

$$
Q=\sqrt{\sum_{i=1}^{5} \frac{1}{5}\left(\frac{q_{i}}{s_{i}}\right)^{2}}
$$

where $s_{i}$ is the number of universities at which $i$ had an appointment.

\section{ACKNOWLEDGMENTS}

This project has received funding from the European Research Council (ERC) under the European Union's Horizon 2020 research and innovation programme under grant agreement No 883033 "Did elite human capital trigger the rise of the West? Insights from a new database of European scholars." We thank Françoise Hiraux, Charles-Henri Nyns, and Violet Soen for comments on an earlier draft.

About the authors: Guillaume was a student in history when he worked as research assistant on the project, and he is now a teacher in Wavre. Valentine is a student in engineering (mining and geology), and works as a research assistant for the project. David is the principal investigator (PI). Julie was also a student in history when she worked as a research assistant on the project, and she has now started a Ph.D. at the University of Namur on "The Man and the Wolf from the 18th to the 20th century". Maximilian is a student in microeconomics and works as a research assistant. Mara has a Ph.D. in anthropology from EHESS and works as a post-doc on the project.

First version September 13, 2021.

\section{REFERENCES}

Alexander, Amir. 2014. Infinitesimal: How a dangerous mathematical theory shaped the modern world. Macmillan.

Applebaum, Wilbur. 2003. Encyclopedia of the scientific revolution: from Copernicus to Newton. New York: Routledge. 
Brants, Victor. 1906. La faculté de droit de l'Université de Louvain à travers cinq siècles <1426-1906>. Louvain: Ch. Peeters.

Cavalieri, Marco. 2019. Humanism today. Enlightened heirs of the Renaissance. Louvain-la-Neuve: Presses Universitaires de Louvain.

Coesemans, Steven. 2019. "Faculties of the Mind. The Rise of Facultative Logic at the University of Louvain.” Ph.D. diss., KULeuven.

De Feller, François-Xavier. 1849. Biographie universelle: ou, Dictionnaire historique des hommes qui se sont fait un nom par leur génie, leurs talents, leurs vertus, leurs erreurs ou leurs crimes. Paris: J. Leroux, Jouby.

De la Croix, David, Frédéric Docquier, Alice Fabre, and Robert Stelter. 2020. "The Academic Market and the Rise of Universities in Medieval and Early Modern Europe (1000-1800)." CEPR Discussion Paper 14509.

De la Croix, David, and Soraya Karioun. 2021. "Scholars and Literati at the Gregorian University in Rome (1551-1773)." Repertorium eruditorum totius Europae 3:19-26.

de Belgique, Académie Royale. 1883. Biographie Nationale. Brussels: Thiry - Van Buggenhoudt.

De la Croix, David. 2021. "Scholars and Literati at the Royal College in Paris (1530-1800)." Repertorium eruditorum totius Europae 1:19-24.

De Ram, Pierre François Xavier de. 1861. Les quatorze livres sur l'histoire de la ville de Louvain du docteur et professeur en théologie Jean Molanus: Historiae lovaniensium. Collection de chroniques belges inédites. Bruxelles: Hayez.

Eloy, Nicolas FJ. 1755. Dictionnaire Historique De La Médecine: Contenant Son Origine, Ses Progrès, ses Révolutions, ses Sectes \& son Etat chez différens Peuples. Bassompierre.

Hiraux, Françoise. 2003. "Introduction." In Collection de cours manuscrits de l'Université de Louvain: 1425-1797: catalogue analytique, edited by Mirguet Françoise and Hiraux Francoise, 13-71. Editions Academia.

Lamberts, Emiel, and Jan Roegiers. 1990. Leuven University, 1425-1985. Leuven: Leuven University Press.

Nève, Félix. 1856. Mémoire historique et littéraire sur le Collège des trois-langues à l'Université de Louvain, en réponse a la question suivante: Faire l'histoire du collège des trois-langues a Louvain,[...]. Hayez.

Paquet, Jacques. 1958. Salaires et prébendes des professeurs de l'Univ. de Louvain au XVe siècle. Léopoldville: Editions de l'Université.

Schwinges, Rainer Christoph, and Christian Hesse. 2019. "Repertorium Academicum Germanicum.” https://en.rag-online.org/.

Stelter, Robert, David De la Croix, and Mikko Myrskylä. 2021. "Leaders and Laggards in Life Expectancy among European Scholars from the Sixteenth to the Early Twentieth Century." Demography 58:111-135.

Tricot-Royer, Joseph JG. 1927. Coup d'oeil sur l'ancienne faculté de médecine de Louvain. F. Ceuterick. UCLouvain. 1874. “Annuaire de l'UCL: 1874." Vanlinthout Frères.

Vander Haeghen, Victor. 1886. Geulincx: étude sur sa vie, sa philosophie et ses ouvrages. Hoste.

Vocht, Henry de. 1951. History of the Foundation and the Rise of the Collegium Trilingue Lovaniense 1517-1550. 3 vols. Louvain: Librairie Universitaire. 